\author{
Mariusz GAMRACKI ${ }^{1}$
}

\title{
REJESTRACJE PIORUNOWEGO POLA ELEKTROMAGNETYCZNEGO PRZEZ STACJE SYSTEMU BLITZORTUNG
}

\begin{abstract}
W pracy opisano możliwości jakie daje system detekcji i lokalizacji Blitzortung pod względem rejestracji przebiegów składowych pola elektromagnetycznego. Początkowe rozdziały opisują podstawy dotyczące działania tego typu systemów, zakresy częstotliwości stosowane przy detekcji wyładowań oraz najczęściej stosowane metody detekcji i lokalizacji wykorzystywane w takich systemach. Dalej opisano działanie systemu detekcji i lokalizacji wyładowań Blitzortung, jego funkcjonalność i rozmieszczenie stacji na świeci. Opisano jak działa system i jakiego typu sygnały są odbierane przez anteny stacji wchodzących w skład systemu. Porównano przebiegi odzwierciedlające składowe magnetyczną i elektryczną pola pochodzącego od wyładowania atmosferycznego. Omówiono parametry numeryczne zastosowane przy detekcji pola przez stacje systemu. Na wybranych przebiegach czasowych pokazano wpływ odległości pomiędzy wyładowaniem atmosferycznym, a stacją detekcji na kształt zarejestrowanych sygnałów pola elektromagnetycznego. Przebiegi porównano także pod względem metody detekcji i rodzaju anten odbierających sygnały pochodzenia piorunowego. W końcowej części pracy opisano możliwości wykorzystania danych z systemu do analizy porównawczej z wynikami symulacyjnymi, z eksperymentów i innych pomiarów.
\end{abstract}

Słowa kluczowe: wyładowanie atmosferyczne, system detekcji wyładowań, pole elektromagnetyczne, składowe magnetyczna i elektryczna

\section{Wprowadzenie}

Wyładowanie atmosferyczne jest zjawiskiem unikalnym i niepowtarzalnym i w zasadzie nie występują dwa identyczne wyładowania. Ze względu jednak na pewne wspólne cechy dotyczące kształtu prądów piorunowych można utworzyć grupę modeli, które charakteryzują poszczególne typy wyładowań. Prowadzone już od kilkudziesięciu lat pomiary i rejestracje zjawisk piorunowych doprowadziły do lepszego poznania kształtów składowych pola elektromagnetycznego powstającego podczas wyładowania atmosferycznego. Kształt fali piorunowej, dla każdego typu wyładowania został opisany w międzynarodowych normach, a w ostatnich latach powstała także norma dotycząca burzo-

${ }^{1}$ Mariusz Gamracki, Politechnika Rzeszowska, ul. W. Pola 2, 17-865-1298, mgamrac@prz.edu.pl 
wych systemów ostrzegawczych [1]. Są tam dokładnie opisane kolejne fazy prądowe występujące podczas wyładowania atmosferycznego, a także zestawione podstawowe techniki używane podczas detekcji i lokalizacji wyładowań. Systemy detekcji podzielone zostały także na cztery klasy wykrywające poszczególne fazy zjawiska [1].

Spektrum częstotliwościowe pola elektromagnetycznego pochodzącego od wyładowania atmosferycznego jest bardzo szerokie. Zaczynając od ekstremalnie niskich częstotliwości $(3 \mathrm{~Hz}-300 \mathrm{~Hz})$, poprzez bardzo niskie (ang. VLF very low frequencies: $3 \mathrm{kHz}-30 \mathrm{kHz}$ ), częstotliwości niskie (ang. LF - low frequencies: $30 \mathrm{kHz}-300 \mathrm{kHz}$ ), częstotliwości średnie i wysokie aż do bardzo wysokich (ang. VHF - very high frequencies: $30 \mathrm{MHz}-300 \mathrm{MHz}$ ) i częstotliwości gigahercowych [1-3]. Tak bardzo duży zakres częstotliwości wynika ze specyfiki zjawiska, a stosowanie odpowiedniej techniki detekcji i związanym z nią przedziałem częstotliwości, w którym analizuje się sygnały, pozwala na pozyskanie informacji także o typie wyładowania: wyładowania doziemne, wewnątrz- i między-chmurowe, dodatnie i ujemne.

\section{Rejestracje wyładowań atmosferycznych przez system Blitzortung}

Stosowane obecnie techniki detekcji wyładowań atmosferycznych bazują najczęściej na analizie częstotliwości z zakresów VLF, LF i VHF [1,2]. Techniki łączące dwa zakresy częstotliwości pozwalają znacznie poszerzyć możliwości detekcji względem metod opartych tylko na jednym zakresie, wymagają jednak zastosowania znacznie bardziej rozbudowanych systemów antenowych niż te stosowane przy analizie w jednym zakresie. Stosowany zakres częstotliwości determinuje zasięg detekcji i możliwość wykrywania określonego typu wyładowań. Największy zasięg detekcji sygnałów mają stacje pracujące na niskich i bardzo niskich częstotliwościach. Ich detekcja sięga nawet tysięcy kilometrów. Pole elektromagnetyczne z zakresów VLF i LF emitowane przez kanał piorunowy jest wyjątkowo silne dla wyładowań głównych doziemnych [2]. System Blitzortung [4] pracuje w zakresach VLF i LF, a zasięg detekcji pojedynczych stacji sięga 10 tyś. $\mathrm{km}$. W wypadku dużego zagęszczenia stacji detekcji na danym obszarze, jak ma to miejsce np. na terenie Europy i USA, nie ma potrzeby wykorzystywania sygnałów zarejestrowanych w odległościach powyżej 5 tyś. km od danej stacji detekcji. Natomiast ze względu na małą ilość stacji, detekcja bez ograniczeń odległości ma miejsce na takich terenach jak Australia, Afryka, państwa dalekiego wschodu (Japonia, Korea Pd.)

Poszczególne stacje wyposażone są w różne typy anten i pracują przy różnych poziomach wzmocnienia w torach kanałów wzmacniaczy. Powoduje to, że rejestrowane sygnały mają różne amplitudy, nawet wtedy gdy wyładowanie zostało zarejestrowane w podobnej odległości od tych stacji. Okazuje się 
jednak, że kształty sygnałów z wielu stacji detekcji są do siebie podobne. Różnice mogą występować jedynie $\mathrm{w}$ fazie (biegunowości) zarejestrowanych sygnałów ponieważ anteny „magnetyczne” poszczególnych stacji mogą być ustawione przeciwsobnie względem anten innych stacji - przeciwny kierunek nawinięcia uzwojeń lub podłączenia przewodów.

Na rysunku 1 pokazano sygnały zarejestrowane przez anteny stacji Rzeszow-Milocin dla bardzo silnego wyładowania, które miało miejsce w dniu 22 maja 2017 roku na terenie Turcji. Pomimo dużej odległości od miejsca wyładowania stacja zarejestrowała „czyste” sygnały, z małą ilością zakłóceń co widać przed chwilą czasu oznaczoną „,0”. Na wykresie czasowym pokazane są trzy przebiegi. Dwa z nich pochodzą od anten składowej magnetycznej (kolory fioletowy i pomarańczowy) natomiast trzeci sygnał (trzeci w legendzie) został zarejestrowany przez antenę składowej elektrycznej (kolor różowy). Wykres poniżej przedstawia widmo częstotliwościowe dla zarejestrowanych sygnałów.
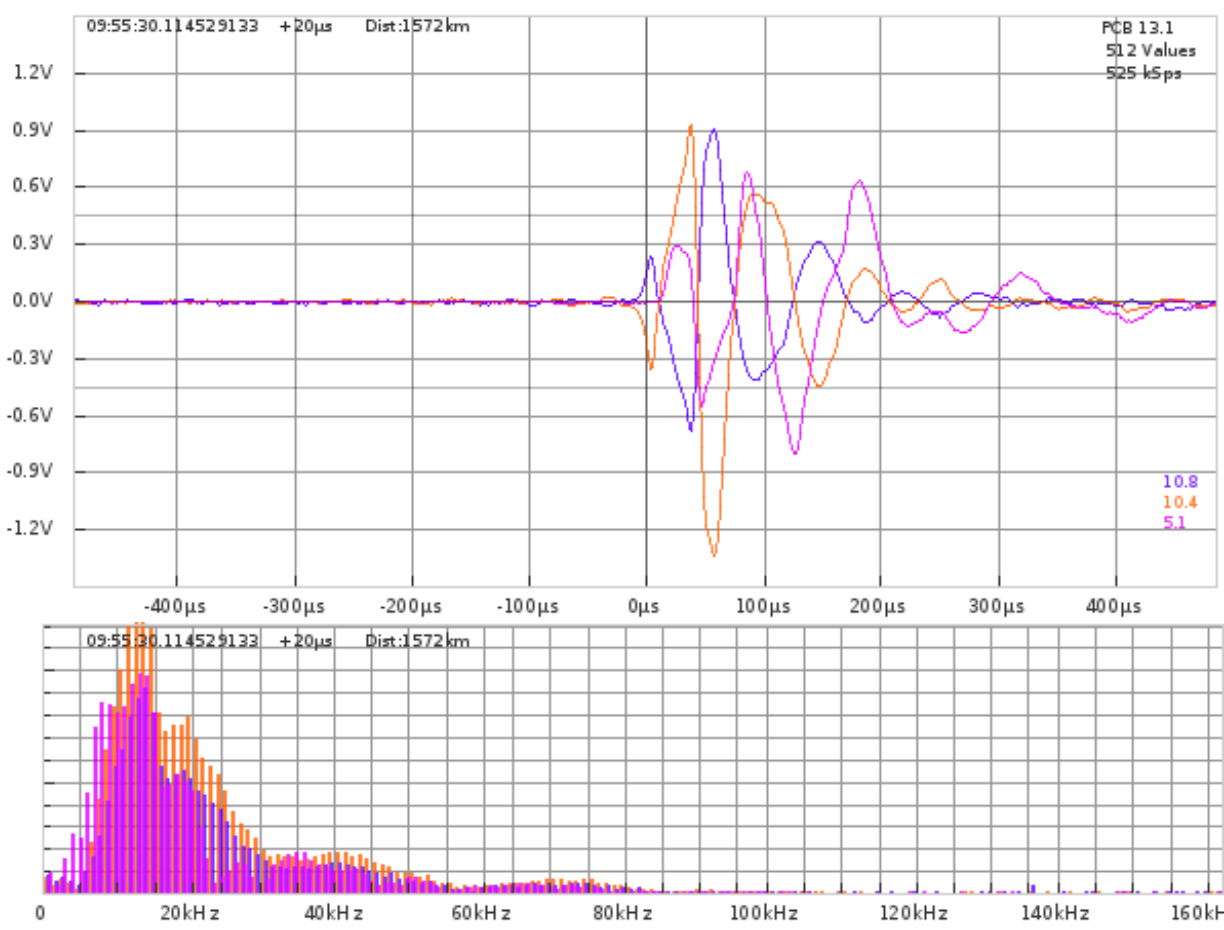

Rys. 1. Sygnały zarejestrowane przez stację Rzeszow-Milocin w Polsce

Fig. 1. Signals recorded by station Rzeszow-Milocin in Poland

Na rysunku 2 pokazano mapę Europy z zaznaczonym miejscem tego wyładowania w pobliżu Turcji, które nastąpiło 22 maja 2017 roku o godzinie 
9:55:31 czasu UTC. Czerwone punkty na mapie oznaczają stacje detekcji. Naniesione linie łączą miejsce wyładowania ze stacjami, które zarejestrowały wyładowanie z czego kolorem zielonym oznaczono linie do tych stacji, z których dane posłużyły do wyznaczenia miejsca lokalizacji wyładowania. Zaznaczone wyładowanie zarejestrowało łącznie aż 530 stacji detekcji głównie na terenie Europy. W przypadku dużej liczby stacji, które zarejestrowały wyładowanie do wyznaczenia współrzędnych miejsca wyładowania używane są dane tylko maksymalnie z 24 stacji, przeważnie najbliższych miejsca wyładowania.

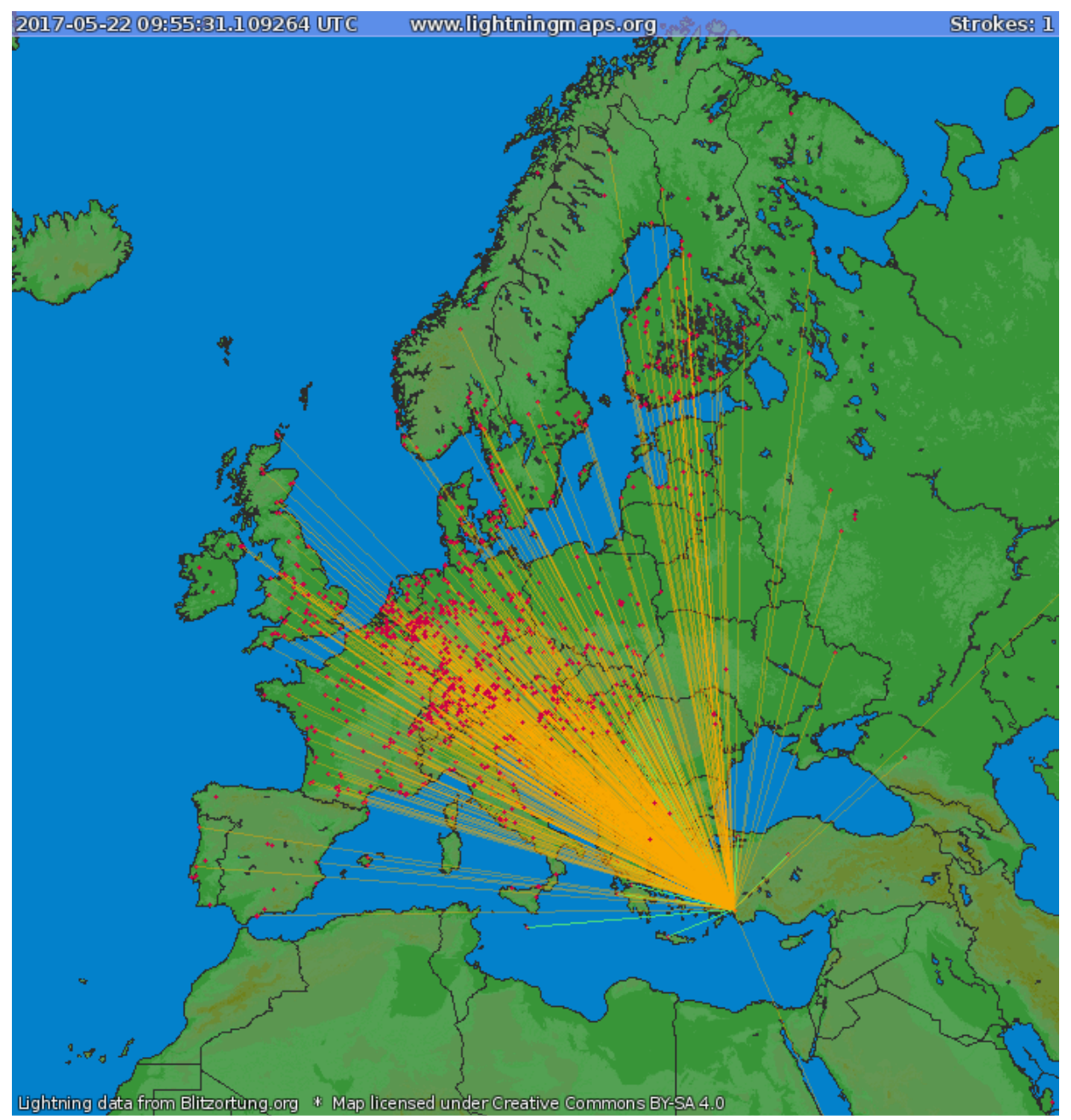

Rys. 2. Mapa ukazująca lokalizację wyładowania w pobliżu Turcji w dniu 22 V 2017 roku [4]

Fig. 2. Map showing the location of lightning nearby Turkey on May 22, 2017 [4] 
Sygnały rejestrowane przez stacje systemu Blitzortung są odzwierciedleniem składowych pola elektromagnetycznego jakie dociera do stacji. Na wykresach widocznych $\mathrm{w}$ kontrolerze i prezentowanych na stronach internetowych systemu oś pionowa jest wyskalowana w woltach i reprezentuje wartości napięć sygnałów, jakie dotarły do kontrolera, a wcześniej wyindukowały się w antenach. Wartości tych napięć zależą od wielu czynników takich jak odległość stacji detekcji od wyładowania, rodzaju wyładowania, wartości prądu pioruna, typu i rodzaju zastosowanych anten ich orientacji oraz aktualnego poziomu wzmocnienia torów wzmacniaczy stacji detekcji jak również zastosowanych dodatkowych filtrów. Dla wyładowań bardzo odległych są to przeważnie ułamki wolta, natomiast dla bardzo bliskich sięgają nawet kilku woltów.

$\mathrm{Na}$ wykresach czasowych podane są także parametry dla zarejestrowanych sygnałów takie jak: dokładny czas UTC (z dokładnością do nanosekundy), odległość wyładowania od stacji w kilometrach, wielkości wzmocnień dla dwóch końcowych stopni wzmacniacza (oddzielone kropką) dla kanałów, które zarejestrowały wyładowanie, liczba próbek oraz częstość próbkowania sygnału. Dla systemu RED na wykresach mogą znaleźć się jednocześnie nawet 4 lub 5 zarejestrowanych sygnałów. Dwa pochodzą wtedy od anten rejestrujących składową magnetyczną pola i aż trzy dla składowej elektrycznej. W najnowszej wersji firmware można wyłączyć dowolne kanały i pozostawić np. dwa sygnały z anten składowej magnetycznej i tylko jeden $\mathrm{z}$ anteny składowej elektrycznej. Jest to dobre rozwiązanie ponieważ do serwerów wysyłanych jest mniej danych, a jakość detekcji w zasadzie nie zmniejsza się. System w wersji BLUE ma możliwość wysyłania już tylko jednego sygnału $\mathrm{z}$ anteny składowej elektrycznej. Wtedy to stacja wysyła maksymalnie 3 lub 4 sygnały, dwa lub trzy z anten składowej magnetycznej i jeden z anteny składowej elektrycznej.

Wzmacniacz składowej elektrycznej pola w wersji RED przepuszcza pojedynczy sygnał pochodzący z anteny „elektrycznej” przez równolegle połączone trzy filtry pasmowe generując $w$ ten sposób trzy przebiegi. Zostało to tak opracowane ponieważ wersja RED była testową wersją dla zastosowanych filtrów dla anteny składowej elektrycznej, spośród których dla wersji BLUE wybrano jeden. Najnowsza wersja systemu BLUE używa tylko jednego kanału dla rejestracji składowej elektrycznej pola. Sygnał przechodzi przez odpowiednio zestawione wzmacniacze i filtry cyfrowe.

Stacje pracujące $\mathrm{z}$ systemem RED najczęściej wyposażone są tylko w jeden typ anten: składowej magnetycznej lub składowej elektrycznej, natomiast systemy BLUE mają już przeważnie dwa typy anten. W sytuacji, gdy poziom sygnału jest niski, może się tak zdarzyć, że stacja zarejestruje sygnał tylko z jednej anteny dlatego też najczęściej na wykresach można zaobserwować 1,2 lub 3 przebiegi. Na wykresach sygnały rysowane są różnymi kolorami, standardowo przypisanymi do poszczególnych kanałów. 


\section{Rejestracje piorunowego pola elektromagnetycznego przez system Blitzortung}

$\mathrm{W}$ tej części pracy przedstawiono przykładowe rejestracje wyładowania, które wystąpiło w pobliżu Grecji w dniu 10 października 2016 roku o godzinie 10:06:39 czasu UTC wykonane przez stacje systemu. Na rysunkach 3-16 przedstawiono rejestracje $\mathrm{z}$ wybranych stacji detekcji rozmieszczone na terenie Europy. Poszczególne rysunki przedstawiają przebiegi dla coraz większych odległości pomiędzy wyładowaniem, a stacjami rejestrującymi na rysunkach oznaczone jako „Dist:” i podane w kilometrach. Jak widać na przebiegach moment rejestracji wyładowania umiejscowiony jest na środku osi czasu. Widać wtedy także część przebiegów przed momentem wyładowania. Ma to czasami znaczenie, ponieważ można wtedy zauważyć zjawiska przed głównym wyładowaniem, które mają na tyle małą amplitudę, że nie spowodowałyby wyzwolenia rejestracji przez stacje detekcji. W kontrolerze można zmieniać ustawienia dotyczące zakresu rejestracji w tym także usytuowania punktu zerowego na osi czasu. Standardowa liczba próbek dla przebiegu to 512 i centralne umiejscowienie punktu zerowego. Częstość próbkowania dla takiego ustawienia wynosi 618 kSps (tysięcy próbek na sekundę) co odpowiada czasowi próbkowania 1,6 $\mu \mathrm{s}$.

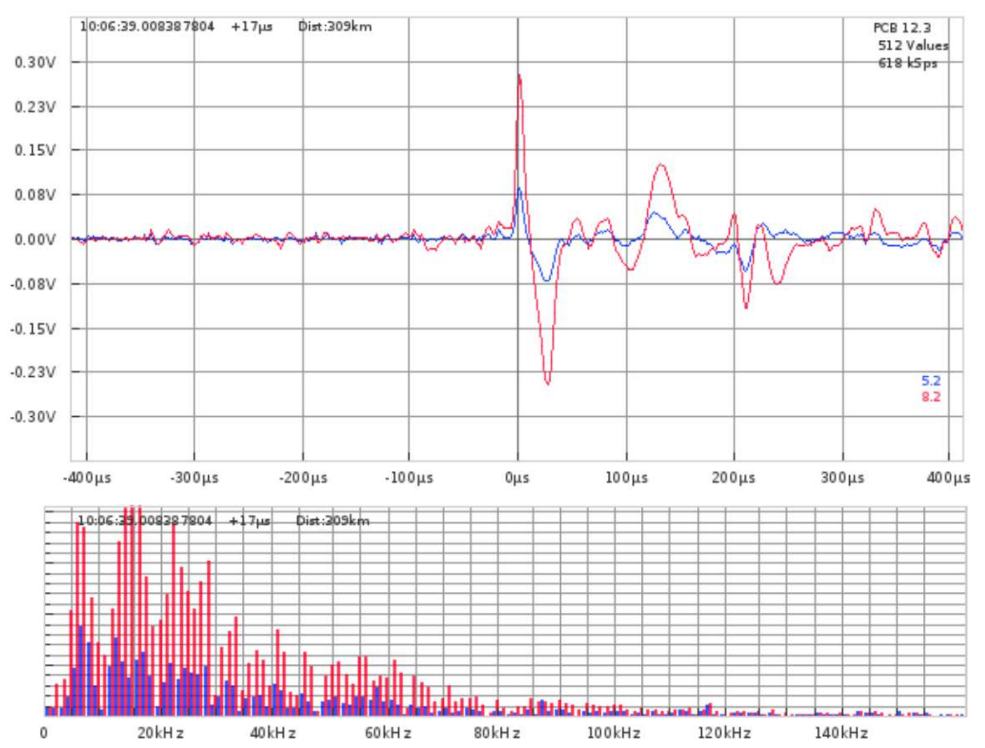

Rys. 3. Sygnały zarejestrowane przez anteny „magnetyczne” stacji Oinoi Viotias w Grecji oraz ich charakterystyki częstotliwościowe

Fig. 3. Signals from station Oinoi Viotias in Greece recorded by the "magnetic" antennas and their frequency characteristics 


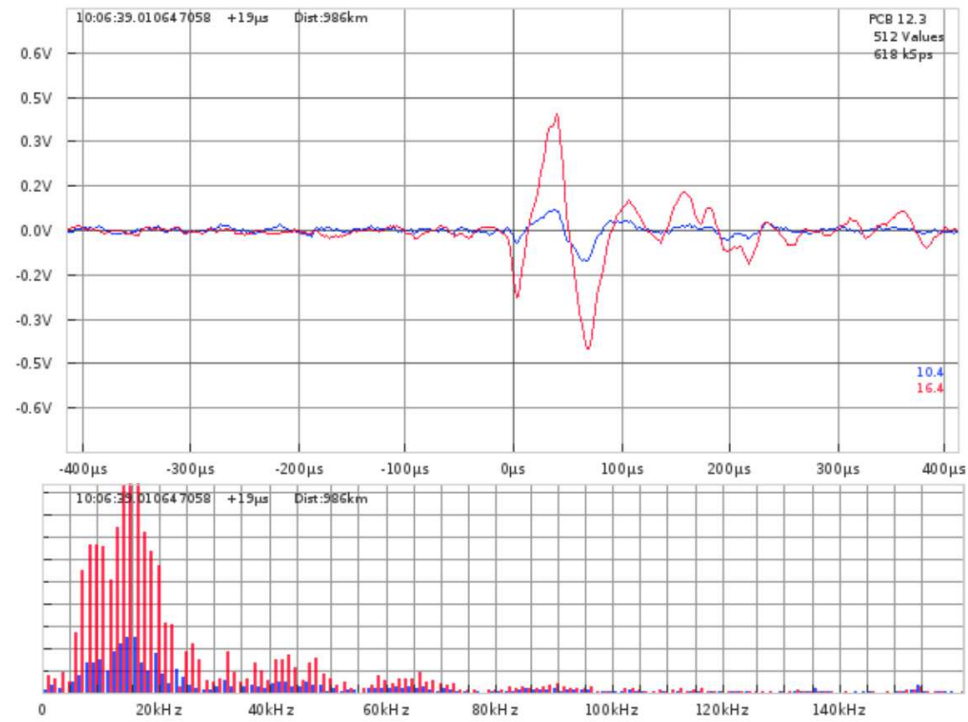

Rys. 4. Sygnały zarejestrowane przez anteny „magnetyczne” stacji ClujNapoca w Rumuni oraz ich charakterystyki częstotliwościowe

Fig. 4. Signals from station Cluj-Napoca in Romania recorded by the "magnetic" antennas and their frequency characteristics

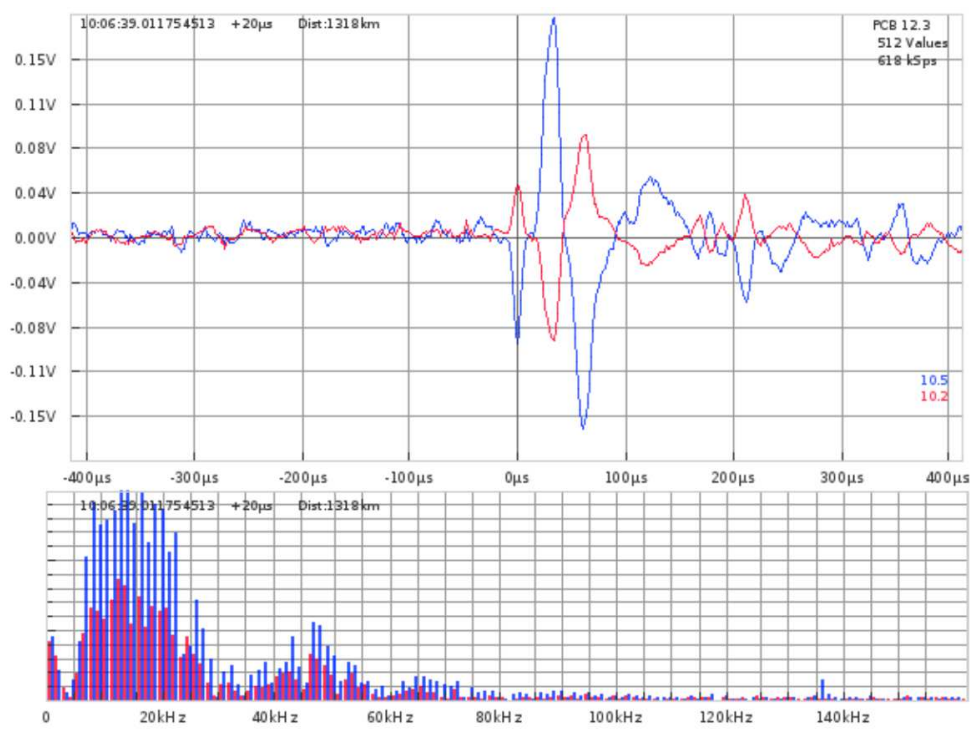

Rys. 5. Sygnały zarejestrowane przez anteny „magnetyczne” stacji Rzeszow-Milocin w Polsce oraz ich charakterystyki częstotliwościowe

Fig. 5. Signals from station Rzeszow-Milocin in Poland recorded by the "magnetic" antennas and their frequency characteristics 
Na charakterystykach częstotliwościowych dołączonych do przebiegów na rysunkach 3-5 widać, że widmo sygnału dochodzi do $160 \mathrm{kHz}$. Ze względu jednak na zastosowane filtry, wysokie częstotliwości są mocno tłumione i użyteczna częstotliwość detekcji sięga ok. $50 \mathrm{kHz}$. Zagadnienia te mają duże znaczenie ponieważ pomagają we właściwym doborze parametrów numerycznych podczas modelowania matematycznego zjawisk piorunowych $[5,6]$.

Ponieważ do anten stacji oprócz sygnałów pochodzenia piorunowego docierają także różnego rodzaju zaburzenia, dlatego też na sygnały piorunowe nakładają się powstające zakłócenia. Wielkość tych zakłóceń zależy przeważnie od „zaszumienia” elektromagnetycznego w pobliżu stacji, ale także od całkowitego wzmocnienia w torach wzmacniaczy. Dla silnego sygnału (np. przy bliskim wyładowaniu) ustawione wzmocnienie dla kanałów wzmacniaczy może być małe co skutkuje małym poziomem zakłóceń. Dla słabego sygnału wzmocnienie musi być większe ponieważ stacja nie zarejestrowała by takiego sygnału.

Sygnały pokazane na rysunkach 3 i 4 są mało zaszumione co wynika z niezbyt dużej odległości wyładowania od tych stacji. Pomimo znacznie mniejszej odległości stacji od wyładowania wartość maksymalna sygnału na wykresie $\mathrm{z}$ rysunku 3 wynosi $0,28 \mathrm{~V}$ i jest mniejsza od wartości max. napięcia na rysunku 4 gdzie wartość ta dochodzi do ok. 0,45 V. Stało się tak, ponieważ wzmocnienie w kanałach (przebiegi czerwone) wzmacniacza stacji rejestrującej sygnał na rysunku 4 wynosi $16 \cdot 4=64$ razy, a wzmocnienie sygnału $z$ rysunku 3 tylko $8 \cdot 2=16$ razy. Sygnały na rysunku 4 są względnie najmniej zaszumione ze wszystkich tu zamieszczonych choć wartość bezwzględna szumów jest dość duża. Przebiegi na rys. 5 mają podobny poziom zakłóceń jak na rysunkach 3 i 4 jednak ze względu na znacznie mniejszą amplitudę sygnału na rysunku 5, szumy są tu bardziej widoczne. Na rysunkach 6 i 7 można zauważyć, że zakłócenia przed wyładowaniem są na podobnym poziomie i wynoszą średnio ok. $\pm 0,02 \mathrm{~V}$.

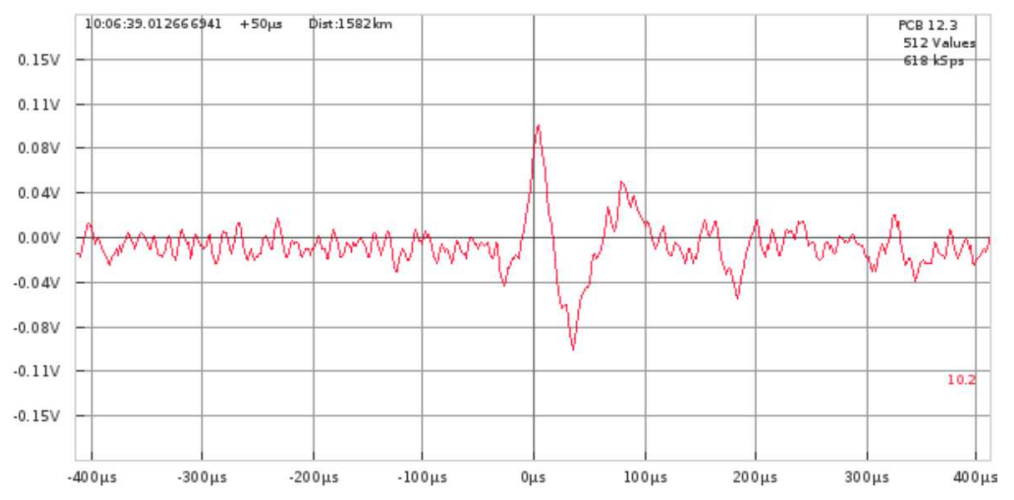

Rys. 6. Sygnał zarejestrowany przez antenę ,,magnetyczną” stacji Lübbenau w Niemczech

Fig. 6. Signal from station Lübbenau in Deutschland recorded by the "magnetic" antenna 


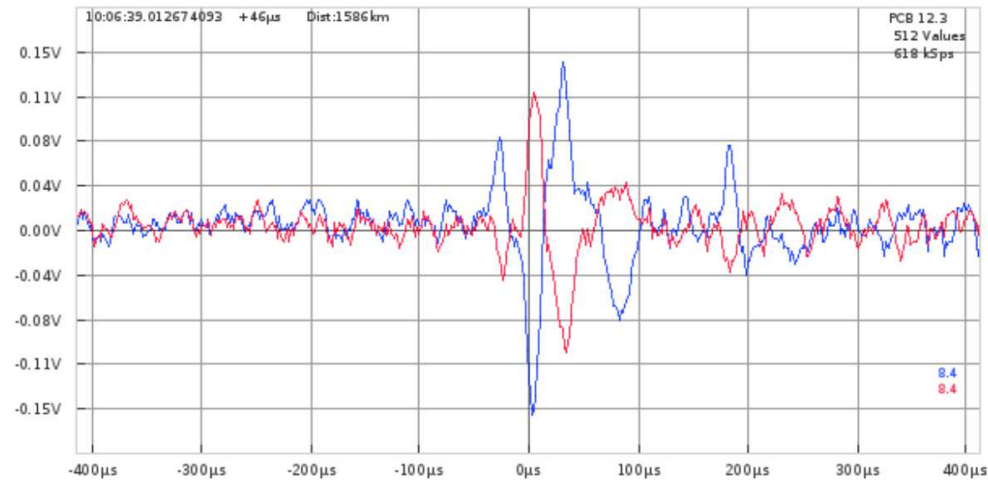

Rys. 7. Sygnały zarejestrowane przez anteny „,magnetyczne” stacji Poznan w Polsce

Fig. 7. Signals from station Poznan in Poland recorded by the "magnetic" antennas

Na rysunkach 5 i 7 można zauważyć podobieństwo kształtów przebiegów. Sygnały są trochę przesunięte w czasie, występuje różnica w poziomach zakłóceń, a przebiegi są „odwrócone”. Na rysunkach 8-10 widać duży poziom zakłóceń nakładających się na sygnały piorunowe. Najmniejszą amplitudę sygnału można zaobserwować na rysunku 9. Pomimo tak małej jej wartości sygnał został zarejestrowany ponieważ napięcie sygnału przekroczyło poziom wyzwalania („trigerowania”). Największy względny poziom zakłóceń występuje na przebiegu z rysunku 10. Jest to już skrajny przypadek rejestracji o bardzo małej wartości poznawczej. Stacja rejestrująca jest położona w odległości aż $2917 \mathrm{~km}$ od miejsca wyładowania. Największe odległości z jakich zostały zarejestrowane sygnały dochodzą do 10 tysięcy kilometrów. Np. stacja Rzeszów-Miłocin zarejestrowała pojedyncze wyładowania w Brazylii, a także w Afryce południowej.

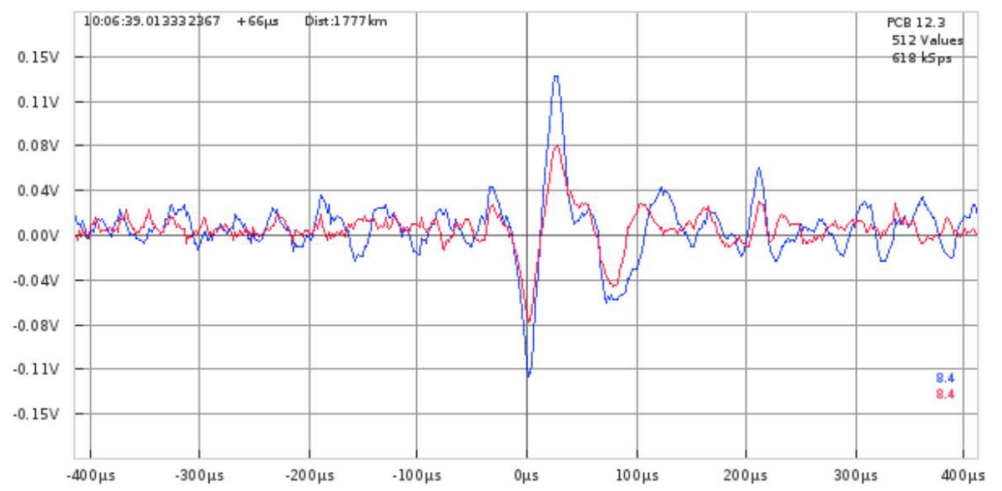

Rys. 8. Sygnały zarejestrowane przez anteny „magnetyczne” stacji Oberhausen w Niemczech

Fig. 8. Signals from station Oberhausen in Deutschland recorded by the "magnetic" antennas 


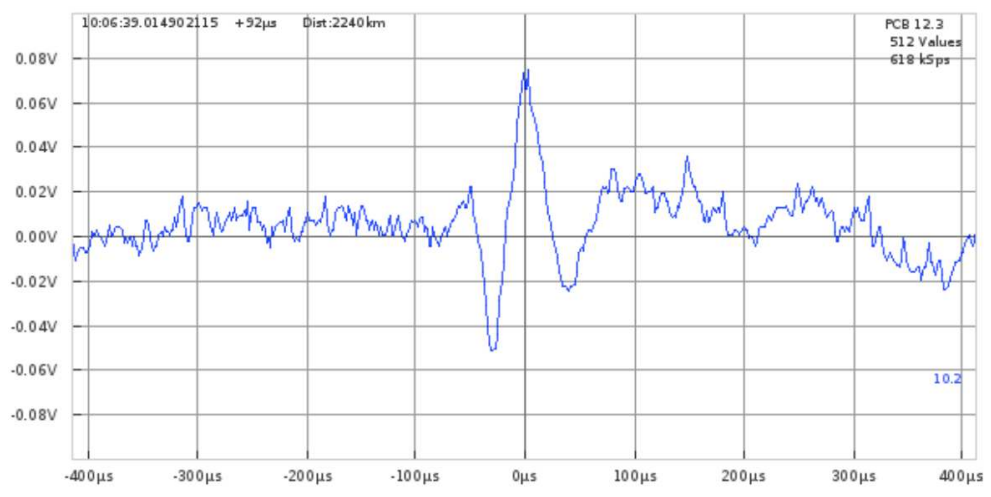

Rys. 9. Sygnał zarejestrowany przez antenę „magnetyczną” stacji Lerum w Szwecji

Fig. 9. Signal from station Lerum in Sweden recorded by the "magnetic" antenna

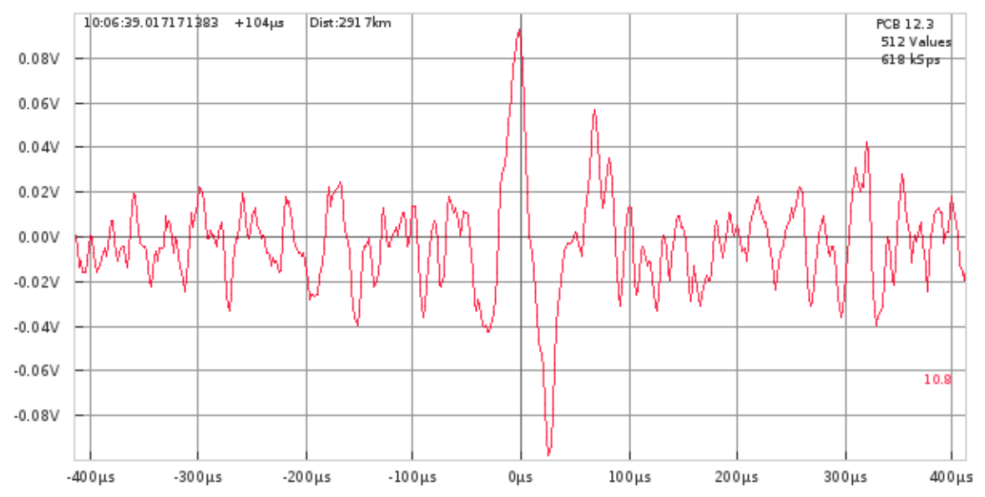

Rys. 10. Sygnał zarejestrowany przez antenę „,magnetyczną” stacji Steinkjer w Norwegii

Fig. 10. Signal from station Steinkjer in Norway recorded by the "magnetic" antenna

Na rysunku 11 przedstawiono rejestrację tego samego wyładowania jednak za pomocą anteny rejestrującej składową elektryczną pola. Pomimo dość dużej odległości wyładowania od stacji rejestrującej poziom zakłóceń jest dość mały. Na rysunku widać odmienny kształt przebiegów względem tych z rysunków od 3 do 10. Rejestracja jest ze stacji pracującej z kontrolerem typu RED, który z jednej anteny generuje trzy przebiegi przechodzące przez trzy różne filtry pasmowe. Antena do detekcji składowej elektrycznej musi być umieszczone w lokalizacji o małym ,zaszumieniu” elektromagnetycznym, najlepiej za zewnątrz budynku (np. na dachu) lub na wysokim maszcie. Oddalenie anteny od innych urządzeń elektrycznych powoduje, że uzyskiwane z niej sygnały są bardzo mało zaszumione. Systemów pracujących z użyciem anten składowej elektrycznej jest na razie niewiele, większość to systemy $\mathrm{z}$ antenami składowej magnetycznej (pętlowe i ferrytowe). W ostatnim roku proporcja ta jednak się zmienia. 


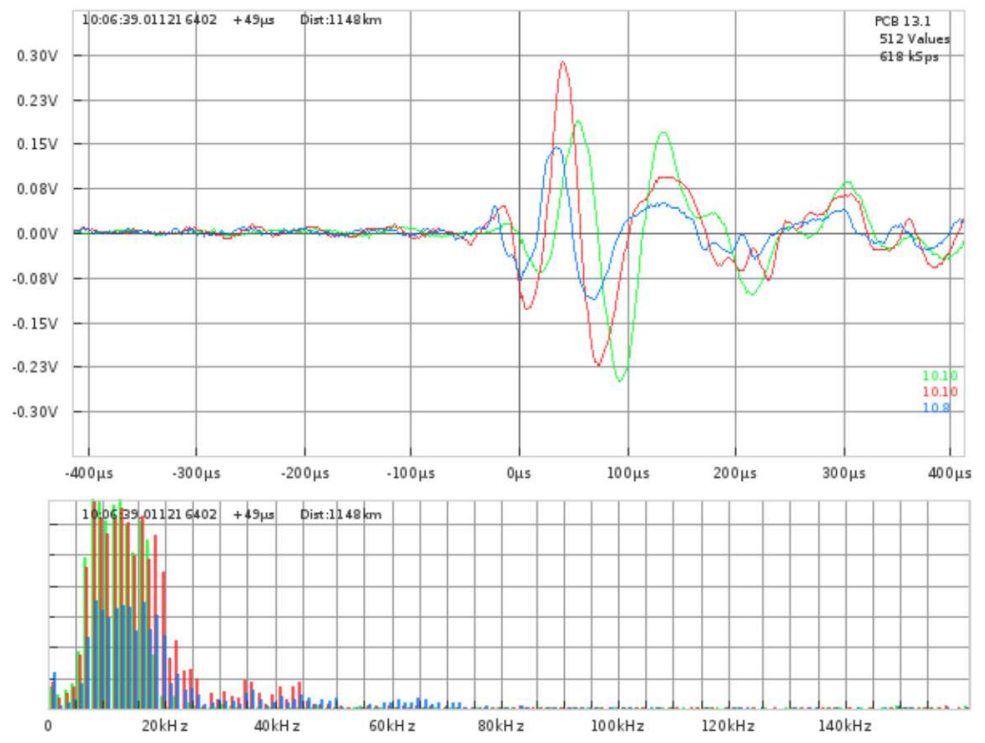

Rys. 11. Sygnały zarejestrowane przez antenę „elektryczną” stacji Monte Penice we Włoszech

Fig. 11. Signals from station Monte Penice in Italy recorded by the "electric" antenna

Wiele sygnałów rejestrowanych przez stacje systemu, pomimo, że są pochodzenia piorunowego, są odrzucane przez serwery ponieważ nie ma dla nich odpowiedników w sygnałach od wymaganej liczby z innych stacji detekcji. Sytuacja taka występuje bardzo często co powoduje wyraźny wzrost liczby sygnałów, które nie są brane pod uwagę podczas lokalizacji wyładowań. Najwięcej jednak ,fałszywych” sygnałów jest pochodzenia lokalnego. Są to różnego rodzaju zakłócenia od urządzeń elektrycznych pracujących w pobliżu. Podobnie dużym problemem są wojskowe stacje nadawcze pracujące na bardzo niskich częstotliwościach, które nawet z odległości kilkudziesięciu czy nawet kilkuset kilometrów mogą powodować poważne zakłócenia.

Na rysunkach 12 i 13 pokazano charakterystyki częstotliwościowe dla torów wzmacniaczy składowej elektrycznej kontrolera w wersji RED. Charakterystyka z rysunku 12 dotyczy dolnego pasma częstotliwościowego. Zamieszczone trzy wykresy dotyczą odpowiednio samego wzmacniacza E-pola (E-Field Amp), samego przedwzmacniacza E-pola (Pre-Amp) i sumy działania całego toru wzmacniaczy składowej elektrycznej pola. Na wykresie można zauważyć, że dolne pasmo przepustowe dla wzmacniaczy zaczyna się od ok. $5 \mathrm{kHz}$ przy czym największe tłumienie wnosi główny wzmacniacz E-pola. Charakterystyka z rysunku 13 pokazuje natomiast tłumienie dla trzech torów wzmacniacza składowej elektrycznej zastosowanego w systemie RED. Główna różnica występuje w górnych częstotliwościach dla poszczególnych torów. Dla wzmocnienia $-5 \mathrm{~dB}$ częstotliwości te wynoszą odpowiednio $18 \mathrm{kHz}, 44 \mathrm{kHz}$ i $50 \mathrm{kHz}$. 


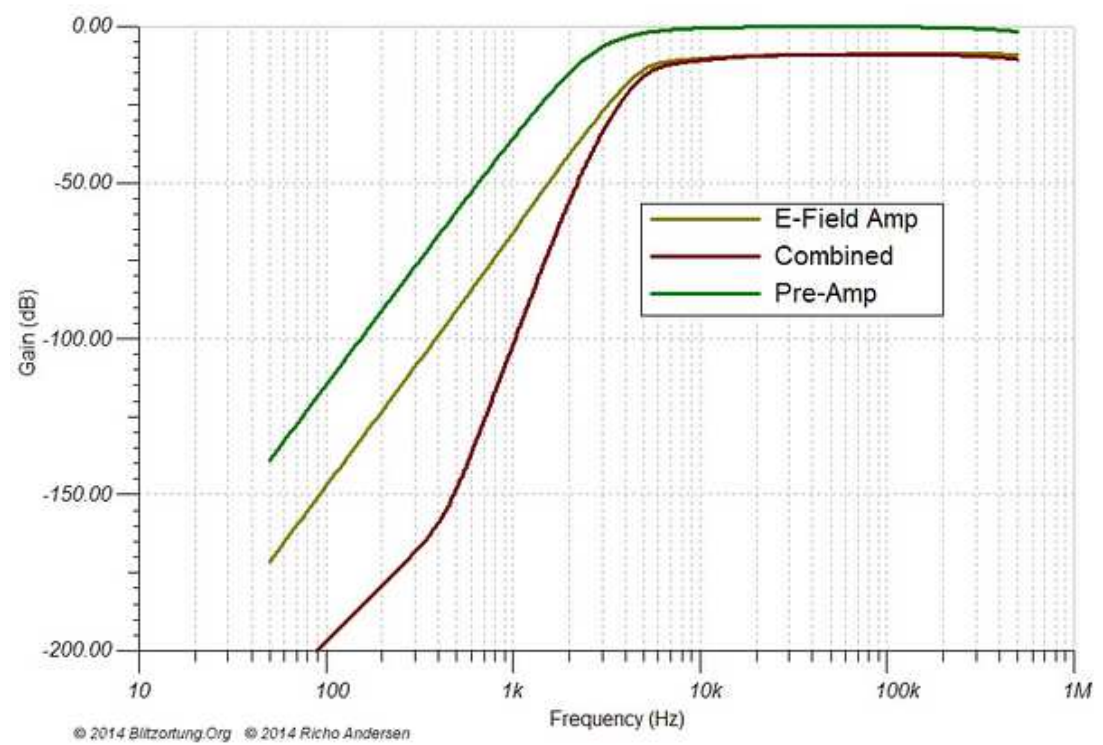

Rys. 12. Charakterystyki częstotliwościowe tłumienia wzmacniaczy składowej elektrycznej [4]

Fig. 12. Frequency characteristics of attenuation of electrical component amplifiers [4]

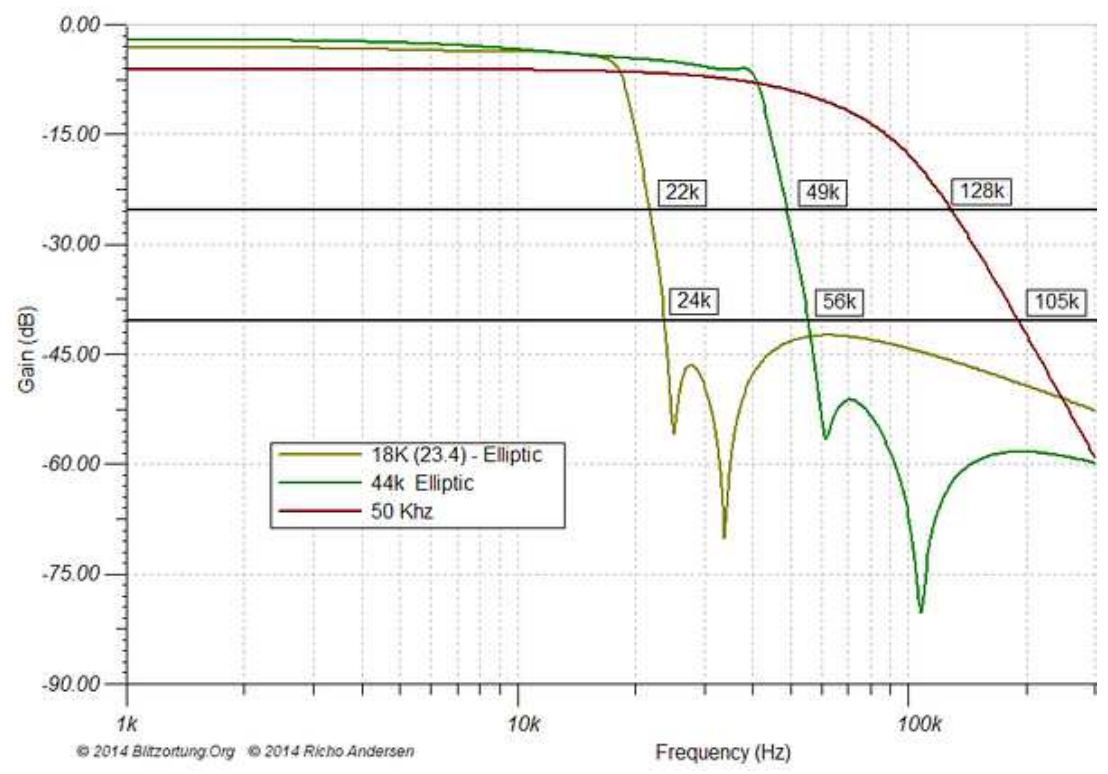

Rys. 13. Górne graniczne częstotliwości trzech torów wzmacniacza składowej elektrycznej [4]

Fig. 13. The upper frequency limit (high-pass filter) of three tracks of electric amplifier [4] 


\section{Wnioski}

Praca jest kontynuacją publikacji [7], gdzie opisano budowę i działanie systemu. Przedstawione przykłady rejestracji pola elektromagnetycznego pokazują możliwości jakie daje system Blitzortung w zastosowaniu do detekcji piorunowego pola elektromagnetycznego. System Blitzortung oprócz swoich podstawowych funkcji związanych z lokalizacją wyładowań umożliwiają wykorzystanie danych $\mathrm{z}$ detekcji do analizy czasowej i częstotliwościowej zarejestrowanych sygnałów. Duża ilość rejestracji wymaga jednak odpowiedniej selekcji danych w celu uzyskania przydatnych wyników. Profesjonalne systemy detekcji i lokalizacji wyładowań pracujące na wysokich i bardzo wysokich częstotliwościach (HF, VHF) dają możliwość bardzo dokładnej analizy czasowej przebiegów jednak zasięg detekcji stacji VHF jest nieduży i dochodzi jedynie do kilkudziesięciu kilometrów $[1,2]$. System Blitzortung pracując na niskich częstotliwościach nie dostarcza precyzyjnych informacji np. o kształcie przebiegów, ale duży zasięg detekcji pozwala na uzyskanie danych ze stacji rejestrujących położonych w różnych odległościach od miejsca wyładowania. Dodatkową korzyścią dla systemów VLF i LF jest możliwość rejestracji sygnałów w stosunkowo długim czasie, gdyż próbkowanie na poziomie 1-2 ms nie generuje nadmiernej ilości danych. Duża ilość stacji detekcji systemu Blitzortung pozwala uzyskać także dużą liczbę rejestracji dla pojedynczego wyładowania piorunowego i to zarówno dla małych jak i dużych odległości pomiędzy wyładowaniem, a stacja rejestrującą. Uzyskane informacje mogą być wartościowym uzupełnieniem podczas analizy danych z profesjonalnych systemów detekcji $[8,9]$, danych pomiarowych w układach rzeczywistych [10] jak również przy modelowaniu matematycznym zjawisk propagacji pola elektromagnetycznego [11-13].

\section{Literatura}

[1] PN-EN 50536. Ochrona przed piorunami - burzowy system ostrzegawczy (2011).

[2] Bodzak P.: Detekcja i lokalizacja wyładowań atmosferycznych, Warszawa 2006, http://www.imgw.pl (2017).

[3] Gamracki M.: Modelowanie matematyczne piorunowych zaburzeń elektromagnetycznych w liniach transmisyjnych, praca doktorska, Politechnika Rzeszowska, Wydział Elektrotechniki i Informatyki, 2004.

[4] Egon Wanke, Richo Andersen, Tobias Volgnandt: World-Wide Low-Cost Community-Based Time-of-Arrival Lightning Detection and Lightning Location Network, 2016, http://www.blitzortung.org.

[5] Bajorek J., Gamracki M.: Effectiveness of mathematical modeling of lightning coupling to overhead conductors, International Conference on Lightning Protection, Kraków, 2002, pp. 208-213.

[6] Bajorek J., Gamracki M., Maslowski G.: Effectiveness of FFT-IFFT transformation during calculation of the electrical pulse underground surface, Proc. 28th Int. Conf. on Lightning Protection, Kanazawa, Japan, 2006, pp. 501-506. 
[7] Gamracki M.: Budowa i działanie systemu detekcji i lokalizacji wyładowań atmosferycznych Blitzortung, Zeszyty Naukowe Politechniki Rzeszowskiej 296, Elektrotechnika 36, nr 1/2017, s. 27-40, p-ISSN 0209-2662, e-ISSN 2300-6358.

[8] Karnas G., Masłowski G.: Preliminary measurements and analysis of lightning electric field recorded at the observation station in the South-east part of Poland, Przegląd Elektrotechniczny, nr 7/2014, s. 97-99, ISSN 0033-2097.

[9] Karnas G., Masłowski G. Barański P.: Power Spectrum Density Analysis of IntraCloud Lightning Discharge Components from Electric Field Recordings in Poland, 33rd International Conference on Lightning Protection, Estoril, Portugal, 2016.

[10] Haddad M.A., Rakov V.A., Cummer S.A.: New measurements of lightning electric field in Florida: Waveform characteristics, interaction with the ionosphere, and peak current estimates, Journal of Geophysical Research, vol. 117, 2012, pp. 1-26.

[11] Gamracki M.: Modelowanie matematyczne propagacji piorunowego zaburzenia elektromagnetycznego nad ziemią, Przegląd Elektrotechniczny, nr 2/2012, s. 23 25, ISSN 0033-2097.

[12] Gamracki M.: Modelowanie propagacji piorunowego zaburzenia elektromagnetycznego nad stratną ziemią, Przegląd Elektrotechniczny, nr 7/2014, s. 171-174, ISSN 0033-2097.

[13] Bajorek J., Gamracki M., Maslowski G.: Modeling of lightning electromagnetic disturbances transmitted into the ground. Proc. XVI International Conference on Electromagnetic Disturbances, Kaunas, Lithuania, 2006, pp. 1132-1137.

\section{REGISTRATION THE LIGHTNING ELECTROMAGNETIC FIELD BY THE STATIONS OF BLITZORTUNG SYSTEM}

\section{S u m m a r y}

The paper describes the possibilities offered by Blitzortung's detection and location system for recording electromagnetic field components. The initial chapters describe the basics for the operation of such systems, the frequency bands used for lightning detection, and the most common detection and location methods used in such systems. Then describes the operation of Blitzortung detection and location system, its functionality and its location the stations. Describes how the system works and what kind of signals are received by the antenna of the system stations. The magnetic and electric fields from the atmospheric discharge were also compared. The numerical parameters used for field detection by the system stations are discussed. On selected waveforms the effect of the distance between the lightning discharge and the detection station in the shape of the recorded electromagnetic field signals is shown. The waveforms were also compared in terms of the detection method and the type of antennas that received signals of lightning origin. The final part of the paper describes the possibilities of using data from the system for comparative analysis with simulation results, experiments and other measurements.

Keywords: Lightning discharge, lightning detection system, electromagnetic field, magnetic and electrical components

DOI: $10.7862 / \mathrm{re} .2017 .7$

Tekst złożono w redakcji: wrzesień 2017

Przyjęto do druku: październik 2017 